\title{
Evaluation of genetic divergence, character associations and path analysis in upland cotton genotypes
}

\author{
Sajida Memon ${ }^{1}$, Abdul Wahid Baloch ${ }^{1 *}$, Naila Gandahi ${ }^{1}$, Tauqeer
} Ahmad Yasir², Saleem Muhammad Sarki ${ }^{3}$, Allah Wasaya ${ }^{2}$, Inayat Ali Mallano ${ }^{4}$, Muharam Ali ${ }^{4}$, Mukhtiar Ali Rind ${ }^{6}$, Abdul Majeed Baloch ${ }^{5}$ and Abdul Sattar Khetran ${ }^{6}$

1. Department of Plant Breeding \& Genetics, Sindh Agriculture University, Tandojam-Pakistan

2. College of Agriculture, Bahauddin Zakariya University, Bahadur Sub-Campus Layyah, Punjab-Pakistan

3. Department of Soil Science, Sindh Agriculture University, Tandojam-Pakistan

4. Department of Biotechnology, Sindh Agriculture University, Tandojam-Pakistan

5. Department of Horticulture, Sindh Agriculture University, Tandojam-Pakistan

6. Agriculture Research Institute, Sariab Road, Quetta-Pakistan

*Corresponding author's email: balochabdulwahid@yahoo.com

Citation

Sajida Memon, Abdul Wahid Baloch, Naila Gandahi, Tauqeer Ahmad Yasir, Saleem Muhammad Sarki, Allah Wasaya, Inayat Ali Mallano, Muharam Ali, Mukhtiar Ali Rind, Abdul Majeed Baloch and Abdul Sattar

Khetran. Evaluation of genetic divergence, character associations and path analysis in upland cotton genotypes. Pure and Applied Biology. Vol. 6, Issue 4, pp1516-1521. http://dx.doi.org/10.19045/bspab.2017.600163

\begin{tabular}{llll}
\hline \hline Received: 24/09/2017 & Revised: 01/12/2017 & Accepted: 10/12/2017 & Online First: 11/12/2017 \\
\hline \hline
\end{tabular}

\section{Abstract}

The present experiment was laid out in randomized complete block design with three replications in order to estimate the genetic divergence, correlation and path analysis in ten upland cotton genotypes. The mean squares revealed highly significant differences $(\mathrm{P}<0.05)$ for all the investigated traits among the tested genotypes, proving that used genetic resources showed a great potential for further breeding experiments. On the basis of mean performance, the variety NB-111 displayed desirable performance for variety of traits, unveiling its importance in cotton breeding programs. The results also exhibited that plant height, bolls plant $^{-1}$, boll weight and seed index developed positive and significant $(\mathrm{P}<0.05)$ associations with seed cotton yield plant ${ }^{-1}$. Pertaining to path analysis, maximum positive direct effects to seed cotton yield palnt ${ }^{-1}$ was contributed by bolls plant ${ }^{-1}$, followed by boll weight, GOT\% and seed index. This demonstrates that genotypes possessing higher extent of these traits may be chosen in selection for developing high yielding cotton genotypes. Considering genetic distance, diverse parents with broad genetic distance were also identified, signifying their importance for upcoming hybridization programs in cotton crop.

Keywords: Genetic distance; Correlation; Path analysis; Upland cotton; Seed cotton yield

\section{Introduction}

Crop improvement primarily refers to the evolution and development of resistant and high yielding crop varieties. The breeding programs are executed generally with the intension to develop varieties with superior qualitative and quantitative traits. However, selection is the most powerful tool for considering a particular trait, which entirely depends on the extent of correlation between yield traits related and seed yield [1]. Crop genetic diversity is a critical component in crop improvement, which helps to identify conservation oriented 
breeding programs. Hence, it is essential to know the relationships among crop varieties and genetic diversity in order to recognize complexity of gene pool and also to identify the gaps in the genotype collections [2]. It has become necessary to exploit the germplasm properly and also to add new germplasm in the existing genetic pool. These practices have enough potential to create sufficient variations to evolve superior genotypes [3]. The variability in the germplasm is responsible to induce resistance against abiotic and biotic stresses. To attain desirable genetic variability, various strategies such as hybridization, exotic germplasm and the polyploidy have been practiced in plant breeding [4]. Correlation is a statistical technique that can show whether and how strongly pairs of variables are related to each other. The correlation coefficient is the extent of linear relationships generally exists among the variables. In breeding, genotypic and phenotypic correlations are applied to determine extent of relationship between yield and yield contributing traits $[5,6]$. These variables could not describe association adequately in case apparent cause-result relationship is found among variables [7]. Therefore these kinds of statistical techniques have immense importance to make the breeding programs successful. Moreover, understanding about the interrelationships among factors influencing yield is fundamental requirement for the development of useful breeding programs [8]. This can also be helpful to identify yield contributing traits [9]. Hence, prior to initiate selection program for crop improvement it is necessary to have knowledge of the relative significance of certain parameters that influence the characters of economic significance in desired direction [10].

\section{Materials and methods}

The current field experiment was conducted at the experimental farm, Department of Plant Breeding and Genetics, Sindh Agriculture University, Tandojam, during kharif season, 2015. Ten upland cotton genotypes were selected for this study and eight characters were investigated (Table 1). The experimental design was laid out in randomized complete block design with three replications. Row to row space was kept at $75 \mathrm{~cm}$ and plant to plant distance was $30 \mathrm{~cm}$. All the recommended agronomic practices and plant protection measures were applied to obtain healthy plants. A total of five plants of each cultivar from each replication selected at random and tagged in the field for observations. The data obtained was subjected to statistical computer package (Statistix Ver. 8.1) for analysis of variance, least significant difference (LSD test) and correlation coefficient. Genetic divergence analysis was carried out with the help of SPSS v.17 computer software.

Table 1. Mean squares for various traits of upland cotton genotypes

\begin{tabular}{|l|l|l|l|l|l|l|l|l|l|}
\hline $\begin{array}{l}\text { Source of } \\
\text { variances }\end{array}$ & $\begin{array}{l}\text { D. } \\
\text { F. }\end{array}$ & $\begin{array}{l}\text { Plant } \\
\text { height }\end{array}$ & $\begin{array}{l}\text { Sympodial } \\
\text { branches plant }\end{array}$ & $\begin{array}{l}\text { Bolls } \\
\text { plant }^{-1}\end{array}$ & $\begin{array}{l}\text { Boll } \\
\text { weight }\end{array}$ & $\begin{array}{l}\text { Seed cotton } \\
\text { yield plant }^{-1}\end{array}$ & $\begin{array}{l}\text { Ginning } \\
\text { outturn }\end{array}$ & $\begin{array}{l}\text { Staple } \\
\text { length }\end{array}$ & $\begin{array}{l}\text { Seed } \\
\text { index }\end{array}$ \\
\hline Replications & 2 & 22.50 & 0.67 & 12.99 & 0.01 & 68.92 & 0.74 & 0.39 & 0.08 \\
\hline Genotypes & 9 & $2049.75^{* *}$ & $74.20^{* *}$ & $151.24^{* *}$ & $0.67^{* *}$ & $3866.5^{* *}$ & $23.44^{* *}$ & $6.42^{* *}$ & $1.16^{* *}$ \\
\hline Error & 18 & 15.42 & 1.72 & 6.8 & 0.04 & 84.06 & 1.03 & 0.57 & 0.11 \\
\hline
\end{tabular}

Note: ** indicates significant level at $1 \%$ of probability level

\section{Results and discussion}

The current study was carried out to assess the genetic divergence, character associations and path analysis in ten elite upland cotton genotypes. The analysis of variance was carried out for eight parameters recorded for seed cotton yield and its related traits. Mean squares displayed that all the characters, including plant height, sympodial branches plant $^{-1}$, bolls plant ${ }^{-1}$, boll weight, seed cotton yield plant $^{-1}$, seed index (100-seed weight, g), staple length and ginning outturn $(\%)$ were highly significant differences $(\mathrm{P} \leq 0.01 \%)$ among the tested genotypes (Table 2). This demonstrates that used genetic resources tend to have useful genetic variations, which may be exploited for further 
breeding programs so as upland cotton genotypes may be improved for variety of traits. Similar to our findings, other researchers, including Baloch et al. [11], Jatoi ([12] and Mugheri [13] also found the significant genetic variance for the number of traits.

Mean performance for various traits of genotypes is given in (Table 2). Results revealed that maximum plant height $(151.80 \mathrm{~cm})$ was attained by NB-111, followed by BH-180 (146.30 cm), while minimum plant height was recorded in IR$1524(82.83 \mathrm{~cm})$. For sympodial branches plant $^{-1}$, maximum sympodial branches were recorded in Lalazar (28.62), followed by CRIS-342 (27.62) and minimum sympodial branches plant ${ }^{-1}$ were recorded in BT-905 (16.46). The major trait in seed cotton yield contributing character is the bolls plant ${ }^{-1}$. It has been generally observed that an increase in number of bolls in cotton plant will in due course increase the seed cotton yield. Regarding bolls plant $^{-1}$, the maximum bolls plant ${ }^{-1}$ (48.21) was set in NB-111; next in rank was the genotype BH180 (41.16); however, minimum bolls plant $^{-1}$ was set in BT-905 (26.66). Boll weight incorporates a major contribution on seed cotton yield because as the boll weight increases, the yield may also increases simultaneously. Concerning parameter boll weight, the maximum boll weight was weighed in CIM-602 (4.01 g), while minimum boll weight was weighed in BT905 (3.12 g). Makhdoom et al. [14] suggested that boll mean weight is the key independent yield component and play a prime role in improving seed cotton yield. Yield is the most important character, which plays a vital role in strengthening the socio-economic conditions of the growers and ultimately the country yield production to its maximum level. For seed cotton yield plant $^{-1}$, maximum seed cotton yield plant ${ }^{-1}$ was produced by the genotype NB-111 $(188.01 \mathrm{~g})$, followed by CIM-602 (162.00 $\mathrm{g}$ ), whereas minimum was produced by the cultivar BT-905 (83.17 g). Fiber length has secured a unique importance among the quality parameters of cotton crop because it is more useful for textile mills in yarn manufacturing. With regard to staple length, longer fiber length was measured in NB-111 (30.08 mm), while minimum was measured in the genotype VH-282 (24.83 $\mathrm{mm})$. As far as seed index is concerned, higher seed index was obtained in NB-111 (7.93 g); nonetheless, lower seed index was achieved in VH-282 (6.20 g). Taking ginning outturn percentage, the maximum ginning outturn was recorded in CIM-602 $(39.66 \%)$, while minimum was reported in Lalazar (31.93\%). All in all, the variety NB-111 displayed better performance in terms of plant height, bolls plant ${ }^{-1}$, seed cotton yield plant ${ }^{-1}$, staple length and seed index. Hence, this identified cotton genotype could be used in upcoming breeding projects so as number of traits can be improved in order to develop desirable cotton varieties.

The estimates of correlation coefficients was worked out among seven yield and fibre quality related characters with seed cotton yield plant ${ }^{1}$ (Table 3 ). Of the total traits, four traits namely plant height $\left(\mathrm{r}=0.778^{* *}\right)$, bolls plant ${ }^{-1}\left(\mathrm{r}=0.873^{* *}\right)$, boll weight $\left(\mathrm{r}=0.759^{*}\right)$ and seed index $\left(\mathrm{r}=0.691^{*}\right)$ developed significant and positive associations with seed cotton yield plant $^{-1}$. Hence, selection for these traits will help in selecting genotypes with higher seed cotton yield plant ${ }^{-1}$. Similar results of positive association between seed cotton yield and its related traits were reported by Baloch et al. ([11], Ashokkumar and Ravikesavan [15] and Kaleri [16]. The inter correlation among the important component traits is also important in order to decide which trait to be given due weightage in exercising selection. The positive and significant inter correlation among the traits was only observed for plant height with bolls plant ${ }^{-1}\left(\mathrm{r}=0.666^{*}\right)$ and boll weight $\left(\mathrm{r}=0.633^{*}\right)$. Similar results were reported by Baloch et al. [11] and Kalpande et al. [17]. However, among the yield contributing traits, it is interesting to note that sympodial branches plant $^{-1}$ 
developed significant but negative inter correlation with ginning outturn percentage $\left(\mathrm{r}=-0.771^{* *}\right)$. It suggests that great care should be taken while selection is being carried out for sympodial branches plant ${ }^{-1}$.

Table 2. Mean performance of upland cotton genotypes for various traits

\begin{tabular}{|c|c|c|c|c|c|c|c|c|}
\hline Characters & $\begin{array}{c}\text { Plant } \\
\text { height } \\
\text { (cm) }\end{array}$ & $\begin{array}{c}\text { Sympodial } \\
\text { branches }^{-1} \\
\text { plant }^{-1}\end{array}$ & $\begin{array}{c}\text { Bolls } \\
\text { plant }^{-1}\end{array}$ & $\begin{array}{c}\text { Boll } \\
\text { weight }(\mathrm{g})\end{array}$ & $\begin{array}{l}\text { Seed cotton } \\
\text { yield plant } \\
\text { (g) }\end{array}$ & $\begin{array}{l}\text { Staple } \\
\text { length } \\
(\mathrm{mm})\end{array}$ & $\begin{array}{c}\text { Seed index } \\
(100 \text {-seed wt, } g)\end{array}$ & GOT\% \\
\hline CRIS-134 & 87.00 & 19.80 & 35.41 & 3.63 & 128.53 & 27.62 & 7.06 & 36.80 \\
\hline IR-1524 & 82.83 & 25.62 & 38.82 & 3.43 & 133.15 & 28.04 & 7.73 & 33.66 \\
\hline Lalazar & 89.86 & 28.62 & 30.65 & 3.19 & 97.77 & 26.78 & 6.26 & 31.93 \\
\hline BT-905 & 83.66 & 16.46 & 26.66 & 3.12 & 83.17 & 28.79 & 6.33 & 36.72 \\
\hline CRIS-342 & 113.46 & 27.62 & 31.20 & 3.40 & 106.08 & 28.11 & 6.46 & 32.26 \\
\hline BH-180 & 146.30 & 22.00 & 41.16 & 3.17 & 130.47 & 29.16 & 6.76 & 39.06 \\
\hline AA-919 & 113.66 & 21.00 & 32.00 & 3.85 & 123.20 & 27.16 & 6.30 & 36.10 \\
\hline VH-282 & 132.33 & 19.66 & 31.66 & 3.89 & 123.15 & 24.83 & 6.20 & 33.53 \\
\hline NB-111 & 151.80 & 25.13 & 48.21 & 3.90 & 188.01 & 30.08 & 7.93 & 38.17 \\
\hline CIM-602 & 126.41 & 17.06 & 40.40 & 4.01 & 162.00 & 26.92 & 7.02 & 39.66 \\
\hline LSD (5\%) & 6.73 & 2.25 & 4.47 & 0.37 & 15.72 & 1.30 & 0.30 & 1.74 \\
\hline
\end{tabular}

Table 3. Correlation coefficient between various traits of upland cotton

\begin{tabular}{|c|c|c|c|c|c|c|c|}
\hline Characters & $\begin{array}{c}\text { Sympodial } \\
\text { branches } \\
\text { plant }^{-1}\end{array}$ & $\begin{array}{c}\text { Bolls } \\
\text { plant }\end{array}$ & $\begin{array}{c}\text { Boll } \\
\text { weight }\end{array}$ & $\begin{array}{c}\text { Seed cotton } \\
\text { yield plant }\end{array}$ & $\begin{array}{c}\text { Staple } \\
\text { length }\end{array}$ & $\begin{array}{c}\text { Seed } \\
\text { index }\end{array}$ & $\begin{array}{c}\text { Ginning } \\
\text { outturn } \\
\text { percentage }\end{array}$ \\
\hline Plant height & -0.270 & $0.666^{*}$ & $0.633^{*}$ & $0.778^{* *}$ & 0.164 & 0.168 & 0.277 \\
\hline $\begin{array}{c}\text { Sympodial } \\
\text { branches plant }^{-1}\end{array}$ & & -0.274 & -0.167 & 0.350 & -0.196 & -0.286 & $-0.771^{* *}$ \\
\hline Bolls plant $^{-1}$ & & & 0.312 & $0.873^{* *}$ & 0.523 & $0.761^{*}$ & 0.392 \\
\hline Boll weight $^{\text {Seed cotton yield }}$ plant $^{-1}$ & & & & $0.759^{*}$ & -0.132 & 0.187 & -0.047 \\
\hline Staple length & & & & 0.326 & $0.691^{*}$ & 0.317 \\
\hline Seed index & & & & & & 0.561 & 0.587 \\
\hline
\end{tabular}

Note: *, ** indicates significant level at 5 and $1 \%$ of probability level, respectively

Path coefficient analysis of seed cotton yield plant ${ }^{-1}$ showed that traits like bolls plant $^{-1}$, boll weight, seed index and ginning outturn percentage depicted highest positive direct effect towards seed cotton yield (Table 4). This is in agreement with the findings of Altaher and Singh [18], An et al. [19] and Magadum et al. [20] for number of bolls plant ${ }^{-1}$ and boll weight, and lint index; Ahuja and Dhayal [21] for number of sympodial branches plant ${ }^{-1}$. The high indirect positive effect on seed cotton yield plant $^{-1}$ was perceived for plant height via bolls plant and boll weight; staple length and seed index through only bolls plant ${ }^{-1}$. Hence, the direct and indirect effects of yield characters such as bolls plant ${ }^{-1}$, boll weight and number of sympodial branches plant $^{-1}$ displayed that these are the major yield contributing characters under intraspecific crosses and may be considered for improving yield in cotton breeding programs.

Considering the genetic distance, it ranged between 10.382 and 134.837. Out of 45 pair of comparisons from genetic distance (Table 5), quite a few numbers of pairs revealed wide genetic distance, such as NB111 and BT-905, followed by NB-111 and CRIS-134, NB-111 and Lalazar, NB-111 and CRIS-342), NB-111 and IR-524, BH180 and BT-905, NB-111 and AA-919 and BH-180 and CRIS-134. Of the special note, these pairs can better be utilized in heterosis breeding programs in cotton crop since these pairs contain variety of genes for 
various traits. However, the narrow genetic distance was found between CIM-602 and BT-905, followed by BT-905 and CRIS134, Lalazar and CRIS-134 and VH-282

Table 4. Path coefficients of seed cotton yield plant with yield related traits

\begin{tabular}{|c|c|c|c|c|c|c|c|c|}
\hline Characters & $\begin{array}{c}\text { Plant } \\
\text { height }\end{array}$ & $\begin{array}{c}\text { Sympodial } \\
\text { branches }^{-1}\end{array}$ & $\begin{array}{c}\text { Bolls } \\
\text { plant }^{-1}\end{array}$ & $\begin{array}{c}\text { Boll } \\
\text { weight }\end{array}$ & $\begin{array}{c}\text { Staple } \\
\text { length } \\
\text { (mm) }\end{array}$ & $\begin{array}{c}\text { Seed } \\
\text { index }\end{array}$ & $\begin{array}{c}\text { GOT } \\
\text { \% }\end{array}$ & $\begin{array}{c}\text { Seed cotton } \\
\text { yield plant }^{-1}\end{array}$ \\
\hline Plant height & -0.221 & -0.052 & 0.501 & 0.447 & -0.027 & 0.023 & 0.106 & 0.778 \\
\hline $\begin{array}{c}\text { Sympodial } \\
\text { branches plant }^{-1}\end{array}$ & 0.06 & 0.191 & -0.214 & -0.118 & 0.031 & 0.119 & -0.300 & 0.350 \\
\hline Bolls plant $^{-1}$ & -0.130 & -0.053 & 0.772 & 0.238 & -0.082 & -0.021 & 0.151 & 0.876 \\
\hline Boll weight & -0.146 & -0.033 & 0.272 & 0.601 & 0.019 & 0.071 & -0.026 & 0.759 \\
\hline Staple length & -0.039 & -0.038 & 0.400 & -0.086 & -0.153 & 0.012 & 0.245 & 0.341 \\
\hline Seed index & -0.039 & -0.057 & 0.391 & 0.159 & -0.098 & 0.240 & 0.102 & 0.699 \\
\hline GOT\% & -0.063 & -0.155 & 0.204 & -0.048 & -0.101 & 0.110 & 0.372 & 0.317 \\
\hline
\end{tabular}

Table 5. Estimation of genetic distance between different upland cotton genotypes

\begin{tabular}{|c|c|c|c|c|c|c|c|c|c|}
\hline Genotypes & CRIS-134 & IR-1524 & Lalazar & BT-905 & CRIS-342 & BH-180 & AA-919 & VH-282 & NB-111 \\
\hline CRIS-134 & 000 & & & & & & & & \\
\hline IR-1524 & 41.909 & 000 & & & & & & & \\
\hline Lalazar & 15.546 & 37.459 & 000 & & & & & & \\
\hline BT-905 & 13.626 & 52.257 & 21.445 & 000 & & & & & \\
\hline CRIS-342 & 29.805 & 48.878 & 23.723 & 35.232 & 000 & & & & \\
\hline BH-180 & 81.852 & 65.902 & 77.867 & 92.039 & 63.856 & 000 & & & \\
\hline AA-919 & 42.328 & 33.034 & 37.517 & 51.910 & 30.214 & 42.386 & 000 & & \\
\hline VH-282 & 55.448 & 51.305 & 50.943 & 64.010 & 34.954 & 32.071 & 19.068 & 000 & \\
\hline NB-111 & 124.054 & 95.736 & 120.208 & 134.837 & 111.099 & 50.837 & 83.990 & 78.572 & 000 \\
\hline CIM-602 & 79.645 & 53.025 & 75.732 & 10.382 & 68.828 & 25.732 & 40.015 & 39.590 & 44.888 \\
\hline
\end{tabular}

\section{Conclusions}

The mean squares indicate that used materials can be evaluated for further experiments. Based on mean performance, the genotype NB-111 exhibited desirable performance for a range of traits, exhibiting its importance in cotton breeding programs. The results also showed that plant height, bolls plant $^{-1}$, boll weight and seed index developed positive and significant $(\mathrm{P}<0.05)$ associations with seed cotton yield plant ${ }^{-1}$. Referring to path analysis, maximum positive direct effects to seed cotton yield palnt $^{-1}$ was added by bolls plant, followed by boll weight, GOT\% and seed index. This reveals that genotypes having higher extent of these traits may be preferred in selection for evolving high yielding cotton genotypes. Considering genetic distance, diverse parents have also been identified, signifying their importance for upcoming hybridization programs in cotton crop. and AA-919. Hence, these pairs of genotypes could be proved reliable breeding materials for backcross breeding. 
traits and molecular markers. Front Agri China 2: 245-252.

4. Esmail RM, Zhang JF \& Abdel-Hamid AM (2008). Genetic diversity in elite cotton germplasm lines using field performance and RAPD markers. World $\boldsymbol{J}$ Agric Sci 4: 369-375.

5. Ali Y, Atta BM, Akhtar J, Monneveux P \& Lateef Z (2008). Genetic variability, association and diversity studies in wheat (Triticum aestivum L.) germplasm. Pak J Bot 40(5): 2087-2097.

6. Turk M \& Celik N (2006). Correlation and path coefficient analyses of seed yield components in the Sainfoin (Onobrychis sativa L.). J Biol Sci 6(4): 758-762.

7. Dokuyucu T, Akkaya A \& Akcura M (2002). Path analysis of yield and some yield related traits of Durum wheat genotypes grown in rain-fed conditions of Mediterranean Region. Turk J Field Crops 7(1): 31-39.

8. Wendel JF \& Crown RC (2003). Polyploidy and the evolutionary history of cotton. Adv Agron 78: 140-186.

9. Baloch MJ, Tunio GH and Lakho AR (1992). Expression of heterosis in $F_{1}$ and its deterioration in intrahirsutum $\mathrm{F}_{2}$ hybrods. Pakphyton 3: 95-106.

10. Falconer DS \& Mackay TFC (1996). Introduction to Quantitative Genetics. (4 ${ }^{\text {th }}$ Ed). Benjamin Cummings. England.

11. Baloch AW, Sahito JA, Ali M, Baloch GA, Abro S, Channa SA, Baloch AM, Baloch GH \& GM Baloch (2014b). Association analysis of yield and fiber traits in advance Pakistani cotton cultivars (Gossypium hirsutum L.). Adv Appl Agri Sci 2(12): 7380.

12. Jatoi SH (2015). Genetic analysis of yield and fiber traits in selected BT cotton germplasm. MSc thesis submitted through department of Plant Breeding and Genetics to Sindh Agriculture Univ. Tando Jam.

13. Mugheri MA (2015). Genetic variablity analysis of some agronomical traits in BT cotton genotypes (Gossypium hirsutum
L.). M.Sc. thesis submitted through department of Plant Breeding and Genetics to Sindh Agriculture Univ. Tando Jam.

14. Makhdoom K, Khan NU, Batool S, Bibi Z, Farhatullah, Khan S, Mohammad F, Hussain D, Raziuddin, Sajjad M \& Khan N (2010). Genetic aptitude and correlation studies in Gossypium hirsutum L. Pak J Bot 42(3): 2011-2017.

15. Ashokkumar J \& Ravikesavan R (2010). Genetic studies of correlation and path coefficient analysis for seed, oil, yield and fiber quality traits in cotton (G. hirsutum L.) Aust J Basic Appl Sci 4 (11): 54965499.

16. Kaleri AA (2015). Assessment of genetic diversity in bt and non bt upland cotton genotypes. M.Sc. thesis submitted through department of Plant Breeding and Genetics to Sindh Agriculture Univ. Tando Jam.

17. Kalpande HV, Bhale SD, Kale UV, Deshmukh JD, Gite VK \& Kakde SS (2008). Genetic variability and correlation studies in $\mathrm{F}_{3}$ generation of cotton (Gossypium hirsutum. L). Int J Plant Sci (3): 94-97.

18. Altaher AF \& Singh RP (2003). Yield components analysis in upland cotton (Gossypium hirsutum L.). J Ind Soc Cotton Improv 28: 151-157.

19. An, DT, Ravikesavan R \& Iyanar K (2008). Genetic advance and heritability as a selection index for improvement of yield and quality in cotton. J Cotton Res Dev 22: 14-18.

20. Magadum S, Banerjee U, Ravikesavan R, Thiyagu K, Boopathi NM \& Rajarathinam S (2012). Association analysis of yield and fibre quality characters in interspecific population of cotton (Gossypium spp.). $J$ Crop Sci Biotech 15(3): 239-243.

21. Ahuja SL \& Dhayal LS (2007). Comparative characteristics and gene action in three petal-spotted mutants of Gossypium hirsutum. J Genet 86: 81-84. 